\title{
KEKERASAN SEKSUAL TERHADAP ANAK: RELASI PELAKU- KORBAN, POLA ASUH DAN KERENTANAN PADA ANAK
}

\author{
Sulastri \\ Fakultas Psikologi Universitas Muhammadiyah Lampung. Email: Sulastri2270@gmail.com \\ ABSTRACT: CHILD SEXUAL ABUSE: PERPETRATOR-VICTIM RELATIONSHIP, PARENTING STYLE, \\ AND CHILD VULNERABILITY
}

Sexual abuse against children, appear in form sexual contact between children and older people (through words, touch, visual images, and exhibitionism), as well as doing sexual contact directly between children and adults (incest, rape, sexual exploitation). This study aims to describe the incidence of child sexual abuse, the victim and perpetrator relationship, parenting style, and vulnerability of children as victims. The study was conducted in the city of Bandar Lampung on 15 child sexual abuse victim. This research used archival research method, which is analyzing 15 chronologies of cases made by victims in certain institutions in Bandar Lampung City. Data collected using documentation method. The results showed that, based on the 15 cases analyzed, anyone had the opportunity to become a perpetrator. Environmental awareness is needed to overcome sexual abuse against children.

\section{Keywor: Child Sexual Abuse, Perpretator-Victim Relationship, Child Vulnerability}

Kekerasan seksual terhadap anak, dapat berupa perlakuan prakontak seksual antara anak dengan orang yang lebih besar (melalui kata-kata, sentuhan, gambar visual, exhibitionism), maupun melakukan kontak seksual secara langsung antara anak dengan orang dewasa (incest, perkosaan, eksploitasi seksual). Penelitian ini bertujuan untuk mendeskripsikan kejadian kekerasan seksual terhadap anak, relasi pelaku dengan korban, modus yang dilakukan, serta mendiskripsikan kerentanan pada anak-anak sebagai korban. Penelitian dilakukan di Kota Bandar Lampung pada 15 anak korban kekerasan seksual. Penelitian ini menggunakan metode penelitian arsip (archival research) yaitu menganalisis 15 kronologi kasus yang dibuat oleh korban.di lembaga tertentu di Kota Bandar Lampung. Teknik pengumpulan data menggunakan metode dokumentasi. Hasil penelitian menunjukkan dari15 kasus yang dianalisis, siapapun mempunyai peluang untuk menjadi pelaku. Kewaspadaan lingkungan sangat diperlukan untuk untuk menanggulangi kekerasan seksual terhadap anak.

\section{Kata Kunci. Kekerasan Seksual Anak, Relasi Pelaku-Korban, Pola Asuh, Kerentanan pada Anak \\ PENDAHULUAN \\ Kekerasan terhadap anak didefinisikan \\ sebagai tindakan melukai yang berulang-ulang \\ secara fisik dan emosional terhadap anak yang \\ ketergantungan, melalui desakan hasrat, \\ hukuman badan tak terkendali, degradasi dan \\ cemoohan permanen atau kekerasan seksual, \\ biasanya dilakukan para orang tua atau pihak \\ lain yang seharusnya merawat anak (Barker \\ dalam Huraerah, 2012). Dalam Ensiklopedia \\ Article from Encarta menyatakan bahwa kekerasan terhadap anak adalah perbuatan disengaja yang menimbulkan kerugian atau bahaya terhadap anak-anak secara fisik maupun emosional (Gelles dalam Huraerah, 2012). \\ Kekerasan seksual merupakan salah satu bentuk dari kekerasan terhadap anak, sedangkan kekerasan seksual adalah tindakan yang mengarah ke ajakan/ desakan seksual}




\section{KEKERASAN SEKSUAL TERHADAP ANAK: \\ RELASI PELAKU-KORBAN, POLA ASUH, DAN KERENTANAN PADA ANAK}

seperti menyentuh, meraba, mencium, dan atau melakukan tindakan-tindakan lain yang tidak dikehendaki oleh korban; memaksa korban menonton produk pornografi, gurauan-gurauan seksual, ucapan-ucapan yang merendahkan dan melecehkan dengan mengarah pada aspek jenis kelamin/ seks korban; memaksa berhubungan seks tanpa persetujuan korban dengan kekerasan fisik maupun tidak; memaksa melakukan aktivitas-aktivitas seksual yang tidak disukai, merendahkan, menyakiti atau melukai korban. (Poerwandari, 2000). Kekerasan seksual terhadap anak adalah salah satu bentuk masalah sosial yang berupa penyimpangan tingkah laku, baik yang dilakukan oleh orang dewasa maupun anak-anak. Pada pelaku orang dewasa, terkadang didorong keinginan untuk mengendalikan anak-anak sehingga anak menjadi korban kekerasan, sedangkan pada pelaku anak dapat menyebabkan anak berhadapan dengan hukum $(\mathrm{ABH})$. Selanjutnya Wahid, Irfan, dan Hasan (2001) menyebutkan bahwa kekerasan seksual merupakan istilah yang menunjukkan pada perilaku seksual deviatif atau hubungan seksual yang menyimpang, merugikan pihak korban dan merusak kedamaian di tengah masyarakat.

Tindakan penganiayaan seksual dapat dibagi atas tiga kategori yaitu perkosaan, incest dan eksploitasi (Resna dan Darmawan dalam Huraerah, 2012):

a. Perkosaan. Pelaku tindakan perkosaan biasanya pria. seringkali terjadi pada suatu saat di mana pelaku lebih dahulu nmengancam dengan memperlihatkan kekuatannya kepada anak. Jika anak diperiksa setelah kejadian, maka alat bukti adalah air mata, darah dan luka memar.

b. Incest. Hubungan seksual atau aktivitas seksual antara individu yang mempunyai hubungan dekat, yang mana perkawinan di antara mereka dilarang oleh hukum maupun kultur. Biasanya terjadi dalam waktu yang lama dan sering menyangkut suatu proses terkondisi.

c. Eksploitasi. Meliputi prostitusi dan pornografi, dan hal ini cukup unik karena sering meliputi suatu kelompok secara berpartisipasi. Dapat terjadi sebagai sebuah kleuarga atau di luar rumah bersama beberapa orang dewasa dan tidak berhubungan dengan anak-anak dan merupakan suatu lingkungan seksual.

Hubungan kedekatan antara pelaku dan korban merupakan hal yang sering menambah kompleksitas dari penanganan kasus kejahatan seksual pada anak, dikarenakan pelaku kekerasan seksual terhadap anak tidak menutup kemungkinan adalah orang tua kandung atau saudara kandung (kasus incest).

Hasil tangkapan Komisi Perlindungan Anak Indonesia pada tahun 2018 untuk kasus kekerasan terhadap anak berjumlah 1434, yaitu untuk anak sebagai pelaku atau korban kekerasan seksual (pemerkosaan, pencabulan, sodomi/ fedopilia. (KPAl, 2018). Data kekerasan pada perempuan dan anak Dinas 
KEKERASAN SEKSUAL TERHADAP ANAK:

RELASI PELAKU-KORBAN, POLA ASUH, DAN KERENTANAN PADA ANAK

Pemberdayaan Perempuan dan Perlindungan

Anak Provinsi Lampung berdasarkan SIMFONI-

PPA per 29 Juli 2019 menunjukkan bahwa terdapat kasus kekerasan terhadap anak sejumlah 109 orang. Kondisi ini sangat memerlukan pemikiran yang serius, agar dapat menurunkan jumlah kasus kekerasan seksual terhadap anak.

Kasus kekerasan seksual terhadap anak merupakan satu jenis kasus yang dilayani oleh lembaga-lembaga yang fokus korbannya adalah anak. Dalam proses layanan, diawali dengan pengaduan dari korban. Pada proses pengaduan korban diminta untuk mengisi form kronologi kasus yang menceritakan semua pengalaman korban, dari penyebab, proses hingga akibat serta upaya yang sudah dilakukan pelaku, tempat kejadian, jumlah pelaku, dan orang yang membantu pelaku melakukan kekeran. Kronologi kasus ini adalah syarat mutlak yang harus diisi oleh korban, dikarenakan layanan selanjutnya tidak akan dilakukan sebelum syarat-syaratnya lengkap. Oleh karena itu, penelitian ini dalam penelitian ini kronologi kasus akan dijadikan bahan pengumpulan data. Melihat banyaknya kasus kekerasan seksual pada anak dan pentingnya penanganan untuk segera dilakukan, maka penelitian ini dilakukan untuk mengetahui segala sesuatu tentang kasus kekerasan seksual.

\section{METODE}

Penelitian ini adalah menggunakan pendekatan deskriptif kualitatif yang bertujuan untuk meringkas serta menggambarkan kondisi, situasi dan fenomena yang menjadi realitas sosial dalam masyarakat, fokusnya adalah untuk mengangkat ciri, karakter, sifat, model atau gambaran yang lebih sfesifik tentang objek penelitian yaitu kasus kekerasan seksual terhadap anak (Nazir, 2003). Untuk proses analisis data, penelitian ini menggunakan metode archival research atau yang lebih dikenal dengan metode penelitian arsip. Metode penelitian arsip adalah sebuah penelitian yang menggunakan arsip, data atau dokumen yang sudah ada, yang kemudiaan digunakan untuk menggali informasi dalam proses penelitian (Shelly, 2009). Data yang dipakai adalah kronologi kasus yang sudah dibuat oleh subyek. Arsip kronologi kasus tersebut dijadikan sebagai sumber informasi primer di dalam proses analisis data penelitian. Kasus yang diambil adalah kasus kekerasan seksual terhadap anak pada bulan Juli dan Agustus dengan setting tempat yang berbeda-beda. Lima belas kasus, diringkas dalam satu tabel yang akan disajikan dan dijabarkan pada tahap penjabaran hasil penelitian nantinya. Peneliti mengamati setiap kasus dari berbagai aspek yaitu pelaku, usia pelaku, relasi dengan korban, siapa yang menjadi korban dan bagaimana pelaku memperlakukan korban. Tujuan dari pengamatan yang dilakukan adalah untuk mengetahui tingkat potensi terjadinya kekerasan seksual pada anak. 
KEKERASAN SEKSUAL TERHADAP ANAK:

RELASI PELAKU-KORBAN, POLA ASUH, DAN KERENTANAN PADA ANAK

HASIL

$$
\begin{aligned}
& \text { Berdasarkan } 15 \text { kasus kekerasan } \\
& \text { seksual terhadap anak yang dianalisis, } \\
& \text { menggambarkan bahwa tempat terjadinya dapat } \\
& \text { di mana saja, seperti terjadi di rumah kosong, } \\
& \text { rumah kontrakan teman, rumah sendiri, }
\end{aligned}
$$

Tabel 2.

\section{Jumlah pelaku kekerasan seksual}

\begin{tabular}{lll}
\hline NO & PELAKU & JUMLAH \\
\hline 1 & Pacar & 2 orang \\
\hline 2 & Teman Pacar & 2 orang \\
\hline 3 & Tetangga & 5 orang \\
\hline 4 & Teman baru kenal & 1 orang \\
\hline 5 & Teman dari teman & 2 orang \\
\hline 6 & Ayah kandung & 2 orang \\
\hline 7 & Kakek kandung & 1 orang \\
\hline & Jumlah & 15 orang \\
\hline
\end{tabular}

\section{DISKUSI}

\section{Faktor penyebab kekerasan seksual terhadap anak}

Menurut Suharto, (Huraerah, 2012) bahwa faktor penyebab kekerasan terhadap anak adalah faktor internal dan faktor eksternal. Faktor eksternal meliputi, a. Anak mengalami cacat tubuh, retardasi mental, gangguan tingkah laku, autisme, anak terlalu lugu, memiliki temperamen lemah, ketidaktahuan anak-anak akan haknya, anak terlalu bergantung pada orang dewasa; b. Kemiskinan keluarga, orang tua menganggur, penghasilan tidak cukup, banyak anak; c. keluarga tunggal atau keluarga pecah (broken home), d. keluarga belum matang secara psikologis, ketidaktahuan mendidik anak, harapan orang tua yang tidak realistis, anak yang tidak diinginkan, anak yang lahir di luar nikah; e. Gangguan mental salah pondokan di pantai dan lain-lain. Sedangkan untuk pelaku adalah orang-orang yang dikenal oleh anak sebagai korban, seperti ayah kandung, pacar, teman, tetangga. satu orang tua; f. Sejarah penelantaran anak; g. Kondisi lingkungan sosial yang buruk. Dalam penelitian ini, secara garis besar bahwa kekerasan seksual terjadi karena faktor gaya hidup, pola asuh, faktor ekonomi keluarga, kelalaian orang tua, kurangnya pengawasan orang tua, ancaman, pemaksaan, moralitas pelaku terutama pada kasus incest, penipuan atau pembohongan.

Pola asuh permisif dari orang tua membuat anak dengan leluasa untuk melakukan hubuangan dan kekerasan seksual pada anak lain. Pola Asuh permisif adalah suatu bentuk pola asuh orang tua dimana didalamnya terdapat aspek-aspek kontrol yang sangat longgar terhadap anak, hukuman dan hadiah tidak pernah diberikan, semua keputusan diserahkan pada anak, orang tua bersikap masa bodoh dan pendidikan bersifat bebas 
Tabel 1.

Analisis Data Kronologi Kasus Kekerasan Seksual pada Anak

\begin{tabular}{|c|c|c|c|c|c|c|c|c|}
\hline No & Tanggal & $\begin{array}{l}\text { Pelakul } \\
\text { Usia }\end{array}$ & Pe-kerjaan & $\begin{array}{l}\text { Hubungan } \\
\text { dengan } \\
\text { korban }\end{array}$ & Korban/Usia & Volume & $\begin{array}{l}\text { Tempat } \\
\text { Kejadian }\end{array}$ & Keterangan \\
\hline 1 & $\begin{array}{l}\text { Selasa,27 } \\
\text { Agustus } \\
2019\end{array}$ & $\begin{array}{ll}\mathrm{Bl}, & 40 \\
\text { tahun }\end{array}$ & Petani & $\begin{array}{l}\text { Ayah } \\
\text { kandung }\end{array}$ & $\begin{array}{l}\text { IR, } 17 \text { tahun, } \\
\text { tidak sekolah }\end{array}$ & 1 & $\begin{array}{l}\text { Rumah } \\
\text { sendiri }\end{array}$ & $\begin{array}{l}\text { 1. Kasus incest (hubungan seksual sedarah) } \\
\text { 2. Ibu menjadi korban KDRT, pergi dan bekerja } \\
\text { 3. Setelah orang tua mengetahui anak } \\
\text { berhubungan dengan pacarnya, anak dipaksa } \\
\text { melayani nafsu bejat ayahnya }\end{array}$ \\
\hline 2 & $\begin{array}{l}\text { Selasa, } 27 \\
\text { Agustus } \\
2019\end{array}$ & $\begin{array}{ll}\mathrm{KL}, & 68 \\
\text { tahun } & \end{array}$ & $\begin{array}{l}\text { Pensiunan } \\
\text { PNS }\end{array}$ & Tetangga & $\begin{array}{l}\text { YS, } 14 \text { tahun, } \\
\text { kelas } 2 \text { SMP }\end{array}$ & 2 & Kontrakan & $\begin{array}{l}\text { 1. Pencabulan } \\
\text { 2. } \quad \text { Bujuk rayu, dengan memberi uang } \\
\text { 3. } \quad \text { Pola Asuh, gaya hidup anak dan faktor } \\
\text { ekonomi keluarga } \\
\text { 4. } \quad \text { Kurangnya perhatian orang tua } \\
\text { 5. Tidak pernah menolak permintaan untuk } \\
\text { melakukan hubungan seksual } \\
\text { 6. } \quad \text { Hamil dan melahirkan } \\
\text { 7. }\end{array}$ \\
\hline 3 & $\begin{array}{l}\text { Senin, } 02 \\
\text { September } \\
2019\end{array}$ & $\begin{array}{l}\text { Jmk (18 } \\
\text { th), Rahm, } \\
\text { Ky, Stp }\end{array}$ & $\begin{array}{l}\text { Satpam, } \\
\text { Tidak } \\
\text { bekerja, }\end{array}$ & $\begin{array}{l}\text { Teman, } \\
\text { teman dari } \\
\text { teman }\end{array}$ & $\begin{array}{l}\text { FZZ E ( } 17 \text { th) } \\
\text { Pelajar SMA }\end{array}$ & $\begin{array}{l}\text { Terminal,kamar } \\
\text { mandi kontrakan, } \\
\text { korban dan pelaku }\end{array}$ & 6 & $\begin{array}{l}\text { 1. Dijanjjikan pergi dan pulang cepat,tetapi } \\
\text { dicabuli } \\
\text { 2. Di bawa kekontrakan, dicabuli } 3 \text { pelaku } \\
\text { (dalam kamar mandi) } \\
\text { 3. Satu orang pelaku menkonsumsi anggur } \\
\text { merah }\end{array}$ \\
\hline 4 & $\begin{array}{l}\text { Rabu, } 03 \\
\text { September } \\
2019 \\
\end{array}$ & TA (16 th), & $\begin{array}{l}\text { Tidak } \\
\text { Sekolah }\end{array}$ & $\begin{array}{l}\text { Teman dari } \\
\text { teman }\end{array}$ & $\begin{array}{l}\text { NKA (12 th) } \\
\text { kelas VI SD }\end{array}$ & $\begin{array}{l}\text { Rumah kontrakan } \\
\text { teman }\end{array}$ & 1 & Kasus perkosaan \\
\hline 5 & $\begin{array}{l}\text { Rabu, } 03 \\
\text { September }\end{array}$ & $\begin{array}{l}\text { BS } \\
\text { th) }\end{array}$ & Pelajar & Pacar & $\begin{array}{l}\text { IN (16 th) } \\
\text { Pelajar SMA }\end{array}$ & $\begin{array}{l}\text { Gubuk di kebun } \\
\text { kelapa }\end{array}$ & 3 & $\begin{array}{l}\text { 1.Dibawa pergi oleh pacar ke Sukadanaham } \\
2 \text { Diajak nonton balap liar, nonton organ }\end{array}$ \\
\hline
\end{tabular}

Sulastri, Fakultas Psikologi Universitas Muhammadiyah Lampung. Email: sulastri2270@gmail.com 
KEKERASAN SEKSUAL TERHADAP ANAK:

RELASI PELAKU-KORBAN, POLA ASUH, DAN KERENTANAN PADA ANAK

\begin{tabular}{|c|c|c|c|c|c|c|c|c|}
\hline & \multirow[t]{2}{*}{2019} & \multirow{2}{*}{$\begin{array}{l}\text { AP } \quad(17 \\
\text { th), } \\
\text { TDS(17 } \\
\text { th) }\end{array}$} & \multirow{2}{*}{$\begin{array}{l}\text { Pelajar } \\
\text { Pelajar }\end{array}$} & \multirow{2}{*}{$\begin{array}{l}\text { T. Pacar } \\
\text { T. Pacar }\end{array}$} & \multirow[t]{2}{*}{ kelas I } & \multirow{2}{*}{\multicolumn{3}{|c|}{$\begin{array}{l}\text { tunggal, } \\
\text { 3. Main ke Pantai, tidak berani } \\
\text { menghubungi pihak keluarga dan melarikan diri } \\
\text { 4. Pergi dari rumah sehari semalam dan } \\
\text { menurut saja ketika diajak pergi kebeberapa } \\
\text { tempat-tempat tertentu }\end{array}$}} \\
\hline & & & & & & & & \\
\hline 6 & $\begin{array}{l}\text { Senin, } 22 \\
\text { Juli } 2019\end{array}$ & $\mathrm{BI}$ (17th) & Pelajar & Tetangga & Cls (5 th) & Tempat umum & 1 & Kasus pencabulan \\
\hline, 7 & $\begin{array}{l}\text { Kamis, } 25 \\
\text { Juli } 2019\end{array}$ & Mbh ( & $\begin{array}{l}\text { Tukang } \\
\text { Balon }\end{array}$ & Baru kenal & KWL (10 th) & Pelecehan seksual & 1 & $\begin{array}{l}\text { 1.Percobaan Pencabulan } \\
\text { 2. Baru kenal, dan diberi uang Rp } 5000 \\
\text { 3. Diajak ke kebun singkong, diancam supaya } \\
\text { mengikuti keinginan pelaku }\end{array}$ \\
\hline 8 & $\begin{array}{ll}\text { Kamis, } & 08 \\
\text { Agustus } & \\
2019 & \end{array}$ & $\operatorname{Tn} . \mathrm{IA}(20)$ & $\begin{array}{l}\text { Tidak } \\
\text { bekerja }\end{array}$ & Pacar & $\begin{array}{ll}\text { Er S, } & 15^{\text {th }} \\
\text { pelajar } & \text { SMA } \\
\text { kelas 1 } & \end{array}$ & $\begin{array}{l}\text { Dekat pantai X, } \\
\text { rumah pelaku, } \\
\text { rumah korban }\end{array}$ & 10 & $\begin{array}{l}\text { 1. Kasus kekerasan seksual } \\
\text { 2. Diawali dari pelecehan seksual, korban marah, } \\
\text { dilanjjutkan hubungan suami istri } \\
\text { 3. Melakukan hubungan badan } 10 \text { kali } \\
\text { 4. Diketahui oleh ayah pelaku, lalu disidang. }\end{array}$ \\
\hline 9 & $\begin{array}{l}\text { Jum'at, } 09 \\
\text { Agustus } \\
2019\end{array}$ & $\mathrm{~N}(17 \mathrm{th})$ & $\begin{array}{l}\text { Tidak } \\
\text { bekerja }\end{array}$ & $\begin{array}{l}\text { Tetangga } \\
\text { depan rumah }\end{array}$ & $\begin{array}{l}\text { El Sa, } 16 \text { th, } \\
\text { babby siter) }\end{array}$ & $\begin{array}{l}\text { Rumah teman, } \\
\text { Rumah kosong }\end{array}$ & 2 & $\begin{array}{l}\text { 1. Diawali penawaran jasa antar, korban } \\
\text { dibohongi, ditarik paksa masuk ke dalam kamar, } \\
\text { dan dipaksa untuk melayani keinginan pelaku } \\
\text { 2. Kejadian ke 2, ditipu untuk berkunjung ke rumah } \\
\text { kerabat saat berangkat sekolah, ternyata rumah } \\
\text { kosong, korban didorong paksa masuk dan } \\
\text { dipaksa melayani, tetap sekolah dengan baju } \\
\text { kusut dan emosi dalam keadaan tertekan }\end{array}$ \\
\hline 10 & $\begin{array}{l}\text { Senin, } \quad 19 \\
\text { Agustus } \\
2019\end{array}$ & KK (68 th) & $\begin{array}{l}\text { Pensiunan } \\
\text { PNS }\end{array}$ & $\begin{array}{l}\text { Kakek } \\
\text { kandung }\end{array}$ & $\mathrm{DA}(1,5)$ & Rumah pelaku & 1 & $\begin{array}{l}\text { 1. Pelecehan seksual } \\
\text { 2. Ibu dan bapak berpisah dan bekerja, korban } \\
\text { dititipkan pada kakek nenek. } \\
\text { 3. Menonton tv dengan kakek, pampers korban } \\
\text { terbuka, dan tangan pelaku ditempel-tempelkan } \\
\text { pada alat kelamin korban, ketauhan ibu }\end{array}$ \\
\hline
\end{tabular}

Sulastri, Fakultas Psikologi Universitas Muhammadiyah Lampung. Email: sulastri2270@gmail.com 
KEKERASAN SEKSUAL TERHADAP ANAK:

RELASI PELAKU-KORBAN, POLA ASUH, DAN KERENTANAN PADA ANAK

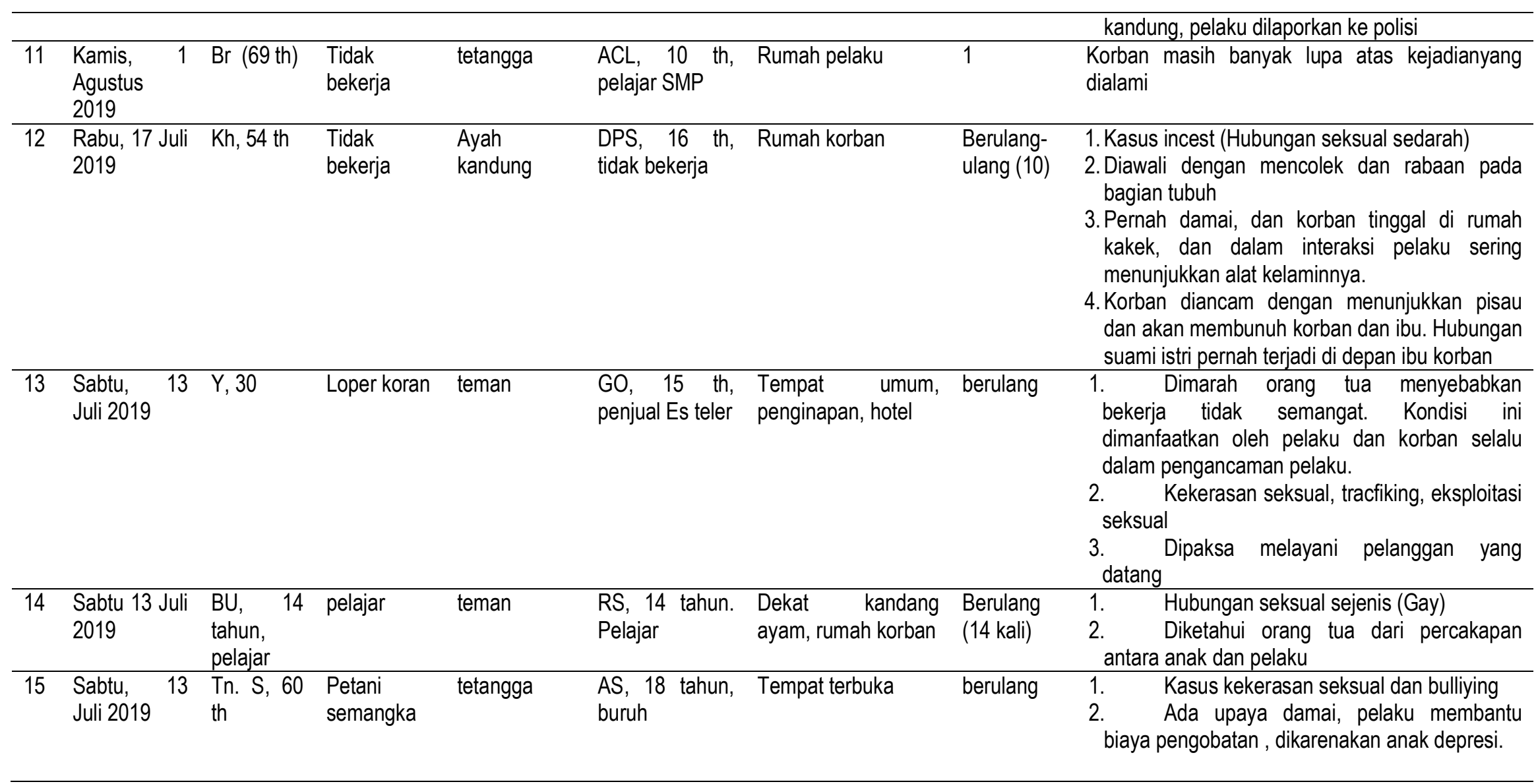

Sulastri, Fakultas Psikologi Universitas Muhammadiyah Lampung. Email: sulastri2270@gmail.com 
(Hurlock,2001). Dengan pola asuh seperti ini, membuat anak bebas untuk bertingkah laku, dikarenakan orang tua tidak membuat suatu aturan yang harus dipatuhi oleh anak. Saat anak mempunyai suatu kebutuhan untuk memenuhi tuntutan gaya hidupnya, apapun dilakukan agar terpenuhi tuntutan gaya hidup tersebut

Fuadi (2011) menyebutkan bahwa factor penyebab terjadinya kekerasan seksual terhadap anak adalah: a. Faktor kelalaian orang tua. Kelalaian orang tua yang tidak memperhatikan tumbuh kembang dan pergaulan anak yang membuat subyek menjadi korban kekerasan seksual; b. Faktor rendahnya moralitas dan mentalitas pelaku. Moralitas dan mentalitas yang tidak dapat bertumbuh dengan baik, membuat pelaku tidak dapat mengontrol nafsu atau perilakunya; c. Faktor ekonomi. Faktor ekonomi membuat pelaku dengan mudah memuluskan rencananya dengan memberikan iming-iming kepada korban yang menjadi target dari pelaku. Pemaksaan dan ancaman, juga dijadikan senjata bagi pelaku untuk melunakkan hati anak sebagai korban. Dalam kasus ini, moralitas pelaku memberikan sumbangan yang sangat berperan, dikarenakan pelaku adalah seorang ayah kandung dan kakek kandung, yang sudah seharusnya memberikan perlindungan terhadap anak dan cucu.

Ditinjau dari hubungan pelaku dengan korban, diketahui bahwa dari 15 sampel, mayoritas dikenal semua oleh korban, dikarenakan walaupun pelaku tersebut adalah teman pacar atau teman dari teman, ternyata korban juga sudah kenal dengan pelaku tersebut. Lebih lanjut, terdapat pula satu kasus yang melibatkan unsur traficking dan eksploitasi seksual, dimana korban dipaksa untuk melayani permintaan pelanggan atau pengunjung, serta di bawah ancaman untuk memenuhi layanan tersebut.

\section{Dinamika Pola Asuh Orang tua dan Potensi Perilaku Menyimpang}

Pada kasus yang ditelaah dalam penelitian ini, terdapat 8 kasus anak sebagai pelaku kekerasan seksual. Hoeve, Dubas, Eichelsheim, Van der Laan, Smeenk, \& Gerris (2009) mengungkapkan bahwa terdapat hubungan antara pola asuh orang tua dengan kejahatan yang dilakukan oleh anak. Hal-hal yang menyebabkan anak berpotensi melakukan tindak kejahatan adalah monitoring dari orangtua, kontrol secara psikologis, penolakan dari lingkungan sosial, dan sikap permusuhan yang diterima oleh anak. Hubungan anak dengan orang tua yang terjalin tidak harmonis, memberikan kontribusi besar pada proses perkembangan anak. Dari perspektif korban, satu orang korban tidak terjalin komunikasi yang baik dan terus berkonflik dengan orang tua. Permasalahan ini membuat korban mencari pengalihan di tempat kerja. Dalam kondisi emosi yang labil, korban dimanfaatkan oleh rekan kerjanya sampai dijadikan objek traficking (perdagangan orang). Hal ini sangat disayangkan, dikarenakan anak harus mendapatkan resiko yang sangat berat dan harus ditanggungnya dalam menjalani kehidupan

Sulastri, Fakultas Psikologi Universitas Muhammadiyah Lampung. Email: sulastri2270@gmail.com 


\section{KEKERASAN SEKSUAL TERHADAP ANAK: \\ RELASI PELAKU-KORBAN, POLA ASUH, DAN KERENTANAN PADA ANAK}

yang kemudian sangat berdampak pada kondisi psikologis anak tersebut

Elvina (2018) menyebutkan bahwa gaya pengasuhan orang tua yang dapat mendukung perkembangan positif anak disebut authoritative parenting. Pola asuh ini mengedepankan dukungan positif untuk anak, kelekatan dengan anak, dan keterbukaan komunikasi untuk berdiskusi dengan anak dalam rangka mengarahkan perilaku anak sesuai norma yang berlaku. Pola asuh autroritatif memberikan pengaruh besar pada anak dalam proses belajar beradaptasi dengan lingkungan sosialnya. Peran orang tua dalam pengasuhan anak berperan signifikan dalam pembentukan perilaku anak. Anak yang lahir dari orang tua yang hangat, intim, komunikatif, penuh cinta, dan penerimaan membuat anak merasa nyaman dan diterima. Teori interaksionisme simbolik juga menunjukkan bahwa adanya komunikasi dua arah antara anak dengan orang tua dapat membantu anak memahami normanorma yang berlaku di masyarakat (Sholihati dalam Elvina, 2018). Dengan demikian, anak tidak mencari "perhatian" atau pelampiasan dengan berbuat tindak kejahatan.

\section{Kekerasan terhadap Anak dari Sudut Pandang Hukum dan Peraturan yang Berlaku}

Dalam Undang-undang Republik Indonesia no 35 tahun 2014 Pasal 4 disebutkan bahwa setiap anak berhak untuk dapat hidup, tumbuh, berkembang, dan berpartisipasi secara wajar sesuai dengan harkat dan martabat kemanusiaan, serta mendapat perlindungan dari kekerasan dan diskriminasi. Pasal 13 disebutkan bahwa setiap anak selama dalam pengasuhan orang tua, wali, atau pihak lain manapun yang bertanggung jawab atas pengasuhan, berhak mendapat perlindungan dari perlakuan:

a. Diskriminasi

b. Eksploitasi, baik ekonomi maupun seksual

c. Penelantaran

d. Kekejaman, kekerasan dan penganiayaan

e. Ketidakadilan, dan

f. Perlakuan salah lainnya. (KPAI, 2018)

Dari kasus-kasus yang ditangani, terdapat kasus kekerasan seksual yang dilakukan oleh keluarga korban sendiri, yaitu ayah dan kakek kandung. Hal ini menunjukkan moralitas yang rendah pada pelaku, dimana pelaku yang seharusnya memberikan perlindungan terhadap anak, justru melakukan kekerasan yang dapat merusak masa depan anak. Pelaku dapat digolongkan telah melakukan perbuatan melanggar hukum dengan ancaman yang tidak bisa di tawar, seperti yang terdapat di dalam Bab IV tentang kewajiban dan tanggung jawa bagian umum Pasal 20 Undang-undang Republik Indonesia no 35 tahun 2014 yaitu: Negara, pemerintah, masyarakat, keluarga dan orang tua berkewajiban dan bertanggung jawab terhadap pernyelenggaraan perlindungan anak (KPAl, 2018)

Sulastri, Fakultas Psikologi Universitas Muhammadiyah Lampung. Email: sulastri2270@gmail.com 


\section{Mengapa anak dijadikan sebagai objek kekerasan seksual?}

Anak dari kelompok tertentu lebih rentan terhadap pelecehan seksual, seperti anak dari keluarga menengah ke bawah, anak yang berasal dari keluarga bercerai, anak yang hidup dengan orang tua tiri atau wali, anak-anak dari keluarga yang melakukan kekerasan, sepeti kecanduan alkohol, obat-obatan dan masalah kesehatan mental (Paulauskas, 2013). Untuk sampel dalam penelitian ini, anak menjadi korban terutama disebabkan oleh kelalaian orang tua dan rendahnya moralitas pelaku (kasus incest, pelaku ayah kandung dan kakek kandung. Anak menjadi lebih rentan menjadi korban kekerasan seksual, karena dibandingkan pelaku, anak cenderung lebih lemah secara fisik, psikologis, ekonomi maupun sosial, sehingga anak cenderung tidak dapat melakukan perlawanan ketika dijadikan sasaran kekerasan seksual. Satu kasus dalam subjek penelitian ini yang pelakunya adalah keluarga kandung, karena anak memiliki keterbatasan dalam kemampuan sosial, akibat aktivitas keseharian yang terbatas pada rumah dan sekolah, korban tidak terlatih untuk melakukan perlawanan terhadap pelaku, meski dari segi waktu dan kesempatan cukup terbuka. Padahal jika anak cukup berani dan tanggap, ia dapat mengambil kesempatan untuk melarikan diri dan menelpon keluarga lain.

\section{SIMPULAN DAN SARAN}

Berdasarkan papaparan di atas, maka dapat disimpulkan bahwa pelaku pada kasus kekeserasan seksual terhadap anak ini dilakukan oleh orang-orang terdekat bagi anak. Potensi untuk menjadi pelaku lebih didominasi oleh anak, yaitu dari 15 kasus anak 8 orang pelaku masih anak-anak. Lebih lanjut, ayah kandung dan kakek kandung menjadi pelaku pada kasus incest sehingga orang tua dan kakek dalam hal ini, tidak bisa dipercaya lagi sebagai orang yang bisa diminta bantuannya untuk menjaga dan mengurus anak selama orang tuanya bekerja. Oleh karena itu, sebagai orang tua, orang-orang terdekat, harus lebih waspada dalam melihat cara pergaulan anak dan lingkungan sekitarnya, hal ini bertujuan untuk mewaspadai terjadinya tindak kekerasan seksual yang dapat merusak masa depan anak. Walaupun sudah terdapat payung hukum yang jelas yang berisikan tentang perlindungan terhadap anak wajib dilakukan oleh siapapun, namun tetap saja kekerasan seksual terjadi di mana-mana

Dari 15 kasus kekerasan seksual terhadap anak yang didapatkan dari kronologis kasus, dapat dikatakan pengasuhan orang tua merupakan solusi utama, karena dapat mendukung perkembangan positif anak. Orang tua diharapkan dapat menerapkan pola asuh autoritatif yang mengedepankan dukungan positif untuk anak, kelekatan dengan anak, dan pemberian arahan perilaku yang melibatkan keterbukaan dalam berkomunikasi.

Hasil penelitian ini dapat menegaskan bahwa siapapun mempunyai peluang untuk menjadi pelaku. Kewaspadaan lingkungan sangat mendukung untuk mengurangi angka kekerasan seksual dan juga merupakansalah satu cara yang untuk

Sulastri, Fakultas Psikologi Universitas Muhammadiyah Lampung. Email: sulastri2270@gmail.com 


\section{KEKERASAN SEKSUAL TERHADAP ANAK: \\ RELASI PELAKU-KORBAN, POLA ASUH, DAN KERENTANAN PADA ANAK}

menanggulangi kekerasan seksual terhadap anak. Bagi anak yang telah menjadi korban, penanganan yang komprehensif dan menempatkan anak sebagai prioritas utama perlu dilakukan untuk memulihkan kondisi psikologis dan mempersiapkan anak mengadapi masa depannya.

\section{DAFTAR PUSTAKA}

Elvina dkk, Putu. (2018). Dampak Pengasuhan dan Upaya Pembinaan Anak Berkonflik Hukum. Refleksi Perbaikan Sistem Peradilan Pidana Anak. Cetakan 1 November 2018. Jakarta: Komisi Perlindungan Anak Indonesia

Fu'ady, M. A. (2011). Dinamika psikologis kekerasan seksual: Sebuah studi fenomenologi. Psikoislamika: Jurnal Psikologi dan Psikologi Islam, 8(2).

Fasalbessy, Jhon D.(2010). Jurnal: Dampak Tindak Kekerasan terhadap Perempuan dan Anak Serta solusinya. Jurnal Sasi Vol 16 No 3 Bulan JuliSeptember 2010

Gerungan (2010). Psikologi Sosial. Refiko Aditama: Bandung

Hoeve, M., Dubas, J. S., Eichelsheim, V. I., Van der Laan, P. H., Smeenk, W., \& Gerris, J. R. (2009). The relationship between parenting and delinquency: A meta-analysis. Journal of abnormal child psychology, 37(6), 749-775.

Hurlock, E. B. (2001). Developmental psychology. Tata McGraw-Hill Education.
Huraerah, Abu.(2012) Kekerasan Terhadap Anak. Bandung: Nuansa Cendikia

Kartono, Kartini (2010). Patologi Sosial Jilid 1. Jakarta: PT. Raja Grafindi Persada

Komisi Perlindungan Anak Indonesia (2018). Laporan Kinerja KPAl Tahun 2018. Peningkatan Efektifitas Kinerja pengawasan Penyelenggaraan perlindungan Anak di Indonesia. Jakarta

Komisi Perlindungan Anak Indonesia (2018). Undangundang Republik Indonesia Nomor 35 tahun 2018 tentang Perubahan Undang-undang Nomor 23 Tahun 2002 Tentang perlindungan Anak dan Undang-undang Republik Indonesia nomor 17 tahun 2016 tentang perpu Nomor 23 tahun 2002 tentang Perlindungan Anak menjadi Undangundang. Jakarta.

Nazir, Moh. (2003). Metode penelitian. Ghalian Indonesia, Jakarta

Paulauskas, R. (2013). Is Causal Attribution of Sexual Deviance the Source of Thinking Errors?. International Education Studies, 6(4), 20-28.

Poerwandari, E. K. (2000). Kekerasan terhadap perempuan: tinjauan psikologi feministik, dalam Sudiarti Luhulima (ed) "Pemahaman Bentukbentuk tindak kekerasan terhadap perempuan dan alternative pemecahannya", Jakarta: Kelompok kerja "convention watch" Pusat Kajian Wanita dan Jender, Universitas Indonesia.

Sugiyono (2018). Metode Penelitian Kuantitaif, Kualitatif, dan R\&D. Bandung: Alfabeta

Wahid, A., Irfan, M., \& Hasan, M. T. (2001). Perlindungan terhadap korban kekerasan seksual: advokasi atas hak asasi perempuan. Refika Aditama. 